\title{
APPEALS BY THE STATE IN CRIMINAL CASES
}

\section{JUSTIN MILLER}

In Connecticut, under a statute permitting the state to take appeals upon all questions of law arising on the trial of criminal cases in the same manner and to the same effect as if taken by the accused, it is held that the state, even after an acquittal, is authorized to appeal and, in case of reversal, to bring the defendant again into court for a new trial. ${ }^{1}$ In Minnesota, the state is not permitted to appeal or seek a review in a criminal case at any time or under any circumstances even on a point of law arising prior to trial, though the trial judge certify the point to the upper court for decision and the defendant consent to the certification. ${ }^{2}$

At a time when the whole subject of criminal law is so much under discussion and the inadequacy of criminal procedure is being particularly decried, the remarkable contrast presented by the laws of these two states deserves attention. Is it proper, on the one hand, that the state should be allowed to carry the man accused of crime to a court of last resort and perhaps back again to the lower court for a new trial after a jury of his peers has declared him innocent? Is it necessary, on the other hand, that the state should be required to acquiesce in a standard of law, pronounced and interpreted exclusively by trial judges, while private litigants in its courts have a right to be heard by an appellate tribunal, and while in other respects the state is regarded as a preferred party against which action cannot be brought except by its consent?

It would be natural to suppose that the diverse procedures used in Connecticut and Minnesota had been adopted only after profound deliberation. As a matter of fact, it cannot fairly be said that the question has been considered on its merits in Minnesota, either by the courts or by the legislature. The statutory provisions in that state relating to appeals and writs of error in criminal cases speak solely in terms of removal by the defendant. ${ }^{3}$ The section relating to certification of the case to the supreme court for determination of a question of law ${ }^{4}$ is indefinite and

\footnotetext{
1 Conn. Gen. Stat. (1918) § 6648; State v. Lee, 65 Conn. 265, 30 Atl. 1110 (1894).

2 State v. McGrorty, 2 Minn. 224 (1858); City of St. Paul v. Stamm, 106 Minn. 81, 118 N. W. 154 (1908) ; State v. Johnson, 139 Minn. 500, 166 N. W. 123 (1918); State v. Wellman, 143 Minn. 488, 173 N. W. 574 (1910); State v. Johnson, 146 Minn. 468, 177 N. W. 657 (1920).

3 Minn. Gen. Stat. (1923) c. 104, § 10747 et seq.

4 Minn. Gen. Stat. (1923) c. 104, § 10756.
} 
uncertain, suggesting that the idea of an appeal by the state was probably never called to the attention of the legislature. In the first Minnesota case in which the question was presented, the court held that the state was not entitled to be heard in the supreme court, reasoning as follows: first, it is very doubtful whether at common law the state was entitled to appeal; second, the earlier New York cases interpreting statutes similar to those in Minnesota denied appeals to the state; third, though New York later changed its laws to permit writs of error to be brought by the state, Minnesota had not done so; and fourth, as the statute provided for the discharge of the prisoner following an order sustaining a demurrer to the indictment and made no provision for rearrest, no appeal or review was contemplated by the legislature. 5 The later cases concede that the legislature might properly provide for state appeals, but hold that in the absence of such legislation the question is concluded by the earlier decisions.

In jurisdictions other than Connecticut and Minnesota, the question has been answered in a variety of ways, covering practically every possibility between the two extremes. A few join with Minnesota in forbidding appeals or reviews on behalf of the state in all cases $;{ }^{\circ}$ in some instances the courts go so far as to decline to consider points raised by the state on appeals taken by defendants. ${ }^{7}$ In some states, appeals are permitted only in the case of major offenses, ${ }^{,}$in others, only in the case of minor offenses. ${ }^{9}$ In a few jurisdictions, even in the absence of statute, it has been held that the state is entitled to a review of a judg-

\footnotetext{
5 State $\nabla$. MIcGrorty, sup;a note 2.

${ }^{6}$ Commonwealth v. Cummings, 3 Cush. 212 (Mass. 1849); Tck. Const. art. 5, § 26; Code Cr. Proc. (1925) art. 812; Prescott v. Statc, 52 Tex. Cr. App. 35, 105 S. W. 192 (1907) ; State v. Morgan, 4 Tex. App. 89 (1873); City of Valdosta v. Goodwin, 21 Ga. App. 664, 94 S. E. 812 (1018). And see note to Kepner v. United States, 1 Ann. Cas. 604 (1906).

7 Prescott v. State, supra note 6; Parlss v. State, 21 Ga. App. 506, 91 S. E. 628 (1917); Bryan v. State, 3 Ga. App. 26, 59 S. E. 1S5 (1907).

8 State v. Harrison, 154 La. 1011, 98 So. 622 (1923); City of Sheridan v. Cadle, 24 Wyo. 293, 157 Pac. 892 (1916) (no appeal in a prosecution for the violation of a city ordinance, appeals by the state being limited to offenses against state laws); State v. Adams, 142 Arli 411, $218 \mathrm{~S}$. W. 845 (1920) (appeal permitted to settle question of law, but no reversal of judgment upon acquittal because the offense was one punishable by 2 fine and imprisonment in the county jail).

9 Baldwin v. Chicago, 68 Ill. 418 (1873); Commonwealth v. Prall, 146 Ky. 109, 142 S. W. 202 (1912) ; Commonwealth v. Gritten, 180 Ky. 410,202 S. W. 884 (1918). These Kentucky cases hold that the state may appeal for the purpose of securing "correct and uniform adninistration of the criminal law" from a judgment on a verdict of aequittal of an offense, the punishment of which is imprisonment, but only in cases where the punishment is a fine can it have a new trial if the previous one resulted in a verdict of acquittal.
} 
ment in favor of the defendant if it is rendered prior to verdict.10 In a number of jurisdictions, statutes have been enacted which permit the state to appeal or to have writs of review on questions of law ${ }^{11}$ (a) as a means of determining the constitutionality of a statute ${ }^{12}$ (b) for the purpose of securing determinations of

10 State v. Buchanan, 5 Harr. \& J. 317 (Md. 1821). Even though tho defendants had been discharged: People v. Swift, 59 Mich. 529, 26 N. W. 694 (1886) (mandamus); Commonwealth v. Capp, 48 Pa. St. 53 (1864) (certiorari).

11 From an order sustaining a demurrer to an indictment or information: State v. Hall, 27 Wyo. 224, 194 Pac. 476 (1921). (Wyo. Comp. Stat. (1910) $\S \S 6242-6245$ ); State v. Robertson, 230 Pac. 932 (Okla. 1924); State v. Walton, 236 Pac. 629 (Okla. 1925).

From a judgment upon an order sustaining a demurrer to an indictment or information: State v. Spencer, 37 S. D. 219, 157 N. W. 662 (1916) (regardless of whether the state had a right to present a new information); People v. Apple, 57 Calif. App. 110, 206 Pac. 487 (1922) (Calif. Penal Code (Deering, 1923) §§ 1238, 1240); State v. Anderson, 119 Wash. 280, 205 Pac. 378 (1922) (Wash. Comp. Stat. (Remington, 1922) § 1716); State v. Rickenberg, 58 Utah, 270, 198 Pac. 767 (1921) (2 Utah Comp. Laws (1917) § 9208, subd. 1).

From a judgment quashing or setting aside an information or indictment: Calif. Penal Code (Deering, 1923) § 1238; District of Columbia v. Horning, 47 D. C. App. 413 (1918) ; State v. Sherman, 144 La. 75, 80 So. 205 (1018); State v. Dennis, 230 Pac. 935 (Okla. 1924).

From a judgment sustaining a special plea in bar: United States v. Schreck, 6 Alaska, 412 (1921) (34 Stat. 1246, (1899) U. S. Comp. Stat. (1916) § 1704); State v. B, 173 Wis. 608, 182 N. W. 474 (1921) (Wis. Stat. (1919) § 4724a); Mich. Comp. Laws (Ann Supp. 1922) § 15842 (1) c. From a ruling admitting evidence over the state's objection: Ex parte Dexter, 93 Vt. 304, 107 Atl. 134 (1919).

From an order granting a writ of habeas corpus: Ala. Code (1923) $\$$ 3238.

From a judgment of an intermediate court reversing a judgment of conviction in the lower court: People v. Merkert, 198 App. Div. 246, 190 N. Y. Supp. 474. (2d Dept. 1921).

From an order arresting judgment: State v. Sherman, supra; State v. Dennis, supra; Calif. Penal Code (Deering, 1923) § 1238; State v. Hall, 183 N. C. 806,112 S. E. 431 (1922); State v. Martin, 94 Wash. 313,162 Pac. 356 (1917); State v. Stratiner, 119 Wash. 667, 206 Pac. 358 (1922). Upon a question reserved by the state: State v. Dennis, supra.

From an order granting a new trial: Calif. Penal Code (Deering, 1023) $\S 1238$; State v. Des Champs, 126 S. C. 416,120 S. E. 491 (1923); Commonwealth v. Metcalfe, $184 \mathrm{Ky} .540,212$ S. W. 434 (1919).

From an order made after judgment affecting the substantial rights of the people: Calif. Penal Code (Deering, 1923) § 1238.

From a final order or judgment made or rendered before jeopardy attached: State v. B, supra.

From a judgment overruling the state's demurrer to a defendant's plea of former jeopardy: Commonwealth v. Anderson, $169 \mathrm{Ky} .372,183 \mathrm{~S}$. W. 898 (1916).

From an order of the court placing the defendant on probation: Stato v. Municipal Court, 179 Wis. 195,190 N. W. 121 (1922); motion for rehearing denied, 179 Wis. 195, 191 N. W. 565 (1923).

12. Mich. Comp. Laws (Ann. Supp. 1922) § 15842 (1); State v. Hall, 
questions of law for use as precedents; ${ }^{13}$ or (c) to secure a better or more uniform administration of the criminal law. ${ }^{36}$ Generally, in such jurisdictions, the law provides that an appeal shall not affect the judgment or bring the defendant back for a new trial but shall be used merely for the determination of questions of law, even though the discharge of the prisoner has followed a determination of innocence made not by a jury but by the court, or though the order directing a verdict of not guilty was made by the court in excess of its power and upon a mistalie of law. This limited privilege of appeal is frequently even more narrowly restricted by interpretation. So it has been held that an appeal is not warranted under such a law from a ruling on the sufficiency of the evidence to sustain a conviction, ${ }^{10}$ or to determine whether the court erred in directing a verdict or compelling an election between counts, ${ }^{17}$ or to challenge a general finding of fact that the defendant was not guilty, made by a court trying the case without a jury. ${ }^{18}$

Equally interesting variations can be found in the laws governing the time when a state appeal can be taken. So, in some jurisdictions, no appeal can be taken before final judgment; ${ }^{19}$ in others, no appeal can be taken after a final judgment, ${ }^{0}$ or after

supra note 11; Wyo. Comp. Stat. (1910) $\$ \$ 6244$, 6245; Ala. Code (1929) § 3239; State v. Street, 117 Ala. 203, 23 So. 807 (1S98); State r. Harold, 128 Ala. 39, 29 So. 592 (1901).

${ }^{13}$ State v. Spahr, 186 Ind. 5S9, 117 N. E. 648 (1917).

14 Ark. Dig. Stat. (Kirby, 1904) § 2603; Arls. Dig. Stat. (Crawiord, 1921) $\S \S 3410,3411$; State v. Buchanan, sitpre note 10.

15.See authorities cited supra note 11; 2 WmLovghay, Cosisritusionas LAW (1910) 822; District of Columbia v. Burns, 82 D. C. App. 203 (1908); People v. Horn, 70 Calif. 17, 11 Pac. 470 (18s6); State v. Speneer, s'7\%o note 11; State v. Walton, supra note 11 .

${ }^{16}$ State v. Smith, 94 Ark. 368, 126 S. W. 1057 (1910).

17 State v. Gray, 160 Ark. 580, 255 S. W. 304 (1923).

18 State v. Millls, 160 Ark. 194, 254 S. W. 468 (1923). And see generally as to this policy of restriction: State v. Harold, supra note 12 (appeal authorized only to test constitutionality of act under which the indictment is preferred). A judgment holding the charter of a municipal corporation unconstitutional does not authorize an appeal; neither does a judgment which holds the act creating the court in which the prosceution is instituted to be unconstitutional. State v. Morris, 39 So. 589 (Ala. 1005) ; 2 Brsuop, New Cerminal Procenure (2d ed. 1913) § 1272.

Under a statute (N. Y. Laws 1880, c. 53S) permitting appeal by the people upon a judgment for the defendant, on a demurrer to the indictrnent, and upon an order of the court arresting judgment, it has been held that the people cannot appeal from an order dismissing an indietment. Pcople v. Herbert, 152 App. Div. 579, 137 N. Y. Supp. 409 (3d Dept. 1912). Or from an order quashing the indictment. People v. Dempsey, 31 Hun, 526 (Sup. Ct. 1884).

19 State v. Sherman, supra note 11; State v. Dickerson, 73 Ohio St. 193, 76 N. E. 864 (1905).

${ }^{20}$ District of Columbia v. Horning, supra note 11; Commonwealth $\because$. Brown, 202 Ky. 604, 260 S. W. 374 (1924); State v. Vincent, 147 Tenn. 
the discharge of the prisoner, ${ }^{21}$ even though the order for judgment be made following a directed verdict.22

This confusion can be explained in part by the historical conditions under which the law relating to criminal appeal was developed. Prior to 1700 there was no right to an appeal or writ of error, even upon the part of a defendant, except as a matter of grace. In the case of Rexv. Wilkes, ${ }^{23}$ Lord Mansfield said:

"Till the 3d of Queen Anne, a writ of error in any criminal case was held to be merely ex gratia. . . . It never was granted, except when the King, from justice, where there really was error, or from favour, though there was no error, was willing the outlawry should be reversed. After a writ of error granted, the Attorney General never made any opposition: because, either he had certified 'there was error', and then he could not argue against his own certificates; or the Crown meant to shew favour, and then he had orders 'not to oppose."

Thereafter the writ of error came to be regarded not merely as a matter of grace but of right whenever there was probably error. ${ }^{24}$ But no appeal was allowed from a verdict of conviction. In 1883, Sir James Stephen said: ${ }^{25}$

"It is a much more important circumstance that no provision whatever is made for questioning the decision of a jury on matters of fact. However unsatisfactory such a verdict may be, whatever facts may be discovered after the trial, which if known at the trial would have altered the result, no means are at present provided by law by which a verdict can be reversed. All that can be done in such a case is to apply to the Queen through the Secretary of State for the Home Department for a pardon for the person supposed to have been wrongly convicted."

The English Criminal Appeal Act of $1907^{26}$ made possible an appeal by a defendant from a conviction and sentence. It abolished writs of error but extended appeals to cover questions formerly considered in connection therewith. But it is generally

458, 249 S. W. 376 (1923) ; State v. Hart, 90 N. J. L. 261, 101 Atl. 278 (1917) ; 1 Vt. Gen. Laws (1917) § 2598; Ex parte Dexter, supra note 11 (review permitted on exceptions taken before judgment, though case taken to Supreme Court).

21 State v. Aurell, 112 Kan. 821, 212 Pac. 899 (1923); State v. Kelsey, 49 N. D. 148, 190 N. W. 817 (1922) ; State v. Meen, 171 Wis. 36, 176 N. W. 70 (1920); State v. Adams, 123 Miss. 514, 86 So. 337 (1920).

22 See cases cited supra note 21; People v. Hastings, 214 Mich. 363, 183 N. W. 10 (1921); United States v. Weissman, 266 U. S. 377, 45 Sup. Ct. 135 (1924); Commonwealth v. Weber, $66 \mathrm{~Pa}$. Super. 180 (1917); Stato v. Spears, 123 Ark. 449, 185 S. W. 788 (1916).

${ }^{23} 4$ Burr. 2527, 2550 (K. B. 1770).

24 Rex v. Wilkes, supra note 23; Stephen, General VIew of the CriminaL LaW (2d ed. 1890) 171; 1 StepheN, History of the Criminat LaW (1883) 308.

251 STEPHEN, op. cit. supra note 24 , at 312 .

26 (1907) 7 Edw. VII, c. $23, \S 3$. 
agreed that the common law did not, ${ }^{2 \pi}$ and the law of England does not now, provide for appeal or writs of error on the part of the prosecution, except that appeals on points of law may be taken in exceptional cases from decisions of the Court of Criminal Appeal to the House of Lords. ${ }^{2 s}$

This condition of the common law left the states practically without guidance, and as a consequence there has been e:sperimentation in the field of criminal appeals, as widespread and confusing as the imaginations of state legislatures could make it. This period of experimentation happened to be coincident with a period of juristic thought which emphasized the liberties or privileges of man and subordinated the powers of government. It followed, too, a period during which defendants were placed at a tremendous disadvantage in criminal courts, appearing as they did without counsel, without witnesses and without the right to be sworn in their own behalf. ${ }^{29}$ These handicaps, suffered by defendants, together with the use of torture in the preliminary stages of prosecution, ${ }^{3 n}$ the very unjudicial activities of magistrates, $^{31}$ the political interest of the government in criminal trials ${ }^{32}$ and the oppression of accused persons generally, ${ }^{33}$ undoubtedly contributed to the development of rules of procedure designed to equalize the positions of the defendant and the state. We would not wish to break down the present safeguards of the accused to a point where he might again be made the victim of persecution. The question is whether it is longer necessary or desirable to deny the state the right to a review by an appellate court of a case tried before a jury, on the theory that an undue advantage would be taken of an acquitted defendant if such review were permitted.

A number of reasons have been given for granting to the defendant and refusing to the state the right of appeal or review. The reason most frequently given is the constitutional guarantee against double jeopardy..$^{34}$ In its essence, the idea of double jeopardy seems to resemble the principle of res adjudicata in

27 United States v. Sanges, 144 U. S. 310, 12 Sup. Ct. 609 (1892) and cases cited. Contra: State v. Buchanan, supia note 10.

${ }^{28}$ Criminal Appeal Act, stepra note 26, at $\$ 1$ (G).

${ }^{29}$ See discussion and collection of authorities on this point in 1 Wigmore, Evmence (2d ed. 1923) 994. See also 3 Chitty, Englisu Statutes (6th ed. 1912) 212 n. (i); People v. Fochtman, 226 ITich. 53, 107 N. W. 166 (1924).

301 STEPHEN, op. cit. supra note 24 , at 222,447 .

311 STEPHEN, op. cit. supra note 24 , at $223,377,422$.

321 STEPHEN, op. cit. supra note 24 , at 418.

331 STEPHEN, op. cit. supra note 24, at 415; Sir John Wedderbourn's Case, Fost. 22, 30 (Cr. Cas. 1746).

3* 2 WhloughbY, op. cit. supra note 15, at S20; Crars, Crmumar ProCEDURE (2d ed. 1918) 453; United States v. Sanges, supra note 27; Commonwealth v. Perrov, 124 Va. 805,97 S. E. 820 (1919); 17 C. J. 14. 
civil proceedings ${ }^{35}$ and, in its earlier development at least, proceeded upon the theory that the accused having been once tried and his case prosecuted to a final conclusion upon its merits, as a matter of public policy it was not desirable that he should be again prosecuted for the same offense.

$35 \mathrm{Ex}$ parte Lange, 18 Wall. 163, 168 (U. S. 1873): "If there is anything settled in the jurisprudence of England and America, it is that no man can be twice lawfully punished for the same offence. . . . The principle finds expression in more than one form in the maxims of the common law. In civil cases the doctrine is expressed by the maxim that no man shall be twice vexed for one and the same cause. Nomo debet bis vescari pro una et eadem causa. It is upon the foundation of this maxim that the plea of a former judgment for the same matter, whether it be in favor of the defendant or against him, is a good bar to an action.

"In the criminal law the same principle, more directly applicable to the case before us, is expressed in the Latin, "Nemo bis punitur pro eodem delicto,' or, as Coke has it, 'Nemo debet bis puniri pro uno delicto.'"

See Williams v. Commonwealth, $78 \mathrm{Ky} .93,96$ (1879); Smith v. Auld, 31 Kan. 262, 266 (1884).

38 4 BL. Comrr. "335: "First the plea of autre-fois acquit, or a former acquittal, is grounded on this universal maxim of the common law of England, that no man is to be brought into jeopardy of his life more than once for the same offence. And hence it is allowed as a consequence, that when a man is once fairly found not guilty upon any indictment, or other prosecution, before any court having competent jurisdiction of the offense, he may plead such acquittal in bar of any subsequent accusation for the same crime. . . .

"Secondly, the plea of autrefois convict, or a former conviction for the same identical crime, though no judgment was ever given, or perhaps will be (being suspended by the benefit of clergy or other causes), is a good plea in bar to an indictment. And this depends upon the same principle as the former, that no man ought to be twice brought in danger of his life for one and the same crime."

2 RUSSELL, CRIMES (8th ed. 1923) 1818: "At common law a man who has once been tried and acquitted for a crime may not be tried again for the same offense if he was 'in jeopardy' on the first trial. He was so 'in jeopardy' if (1) the Court was competent to try him for the offence; (2) the trial was upon a good indictment, on which a valid judgment of conviction could be entered; and (3) the acquittal was on the merits, $i$. $c$. by verdict on the trial, or in summary cases by dismissal on the merits followed by a judgment or order of acquittal" [our italics].

The doctrine has been considerably extended in the United States. It is generally stated now not in terms of prosecution to a final conclusion upon the merits but in terms of "commencement of the trial." State v. Keerl, 33 Mont. 501, 516, 85 Pac. 862, 864 (1906); aff'd 213 U. S. 135, 29 Sup. Ct. 469 (1909). Or "the impaneling of the jury." Gillespie v. State, 168 Ind. 298, 310, 317, 80 N. E. 829, 833, 836 (1907). Or "charging the jury with the deliverance of the accused," which is defined as having occurred when the jury is impaneled and sworn to try the accused upon a valid indictment in a competent court. Allen v. State, 52 Fla. 1, 41 So. 593 (1906) and cases cited. And in Kepner v. United States, 195 U. S. 100, 128, 24 Sup. Ct. 797, 804 (1904) it was held that "where one has been tried before a competent tribunal having jurisdiction he has been in jeopardy as much as he could have been in those tribunals where a jury is alone competent to convict or acquit" [our italics]. 
When we stop to consider that neither the ling nor the accused could take an appeal, we see at once the reason of the rule which made former jeopardy turn on former conviction or former acquittal. At that point the case was actually, finally determined, presumably upon its merits, and there would have been neither reason nor justice in a rule which would have permitted a second trial. However, as time went on and appeals came to be allowed upon behalf of accused persons, the situation was changed and the determination of the case in the trial court was no longer a final one. It became common practice, following such appeals, to bring the accused again to trial, and to deny his plea of former jeopardy based upon the former conviction. This is now generally recognized as an exception to the rule that a former conviction bars further prosecution. ${ }^{37}$

It would seem to be a logical further step to permit appeals by the state and again to modify the jeopardy doctrine to permit new trials following successful state appeals from acquittals. This is exactly what has been done and exactly the position talien by Connecticut in the statute and cases previously referred to. In State v. Lee, ${ }^{38}$ the decision reads as follows:

"This maxim is based upon a principle common to all systems of jurisprudence, i.e., the finality of judicial proceedings. -. The principle nemo bis verare pro cadcin causa, gives protection against a second judicial proceeding, and in the event of such proceeding gives to a party the right, in criminal cases, to the plea of autrefois acquit or autrefois convict, and in civil cases to the plea of res judicata; but the principle does not control the question whether the judgment pleaded in bar is in fact a legal and final judgment, and has no legitimate relation to the question whether existing procedure provides for correction of errors occurring in the trial. . . And so the putting in jeopardy means a jeopardy which is real and has continued through every stage of one prosecution, as fixed by existing laws relating to

37 ClakK, op. cit. supra note 34, at $451 ; 1$ Bishop, Crisiriar LaTy (9th ed. 1923) 740, 741. A number of other exceptions are also rceognized. See, for illustrations, the following:

United States v. Riley, Fed. Cas. No. 16,164 (C. C. S. D. N. Y. 1S61); State v. Rook, 61 Kan. 382, 59 Pac. 653 (1900); State v. Hansford, 76 Kan. 678, 92 Pac. 551 (1907); Simmons v. United States, 142 U. S. 143, 12 Sup. Ct. 171 (1891); see State v. Nelson, 26 Ind. 866 (1806).

Ox the death of a juror's mother. Stocks v. State, 91 Ga. 831, 18 S. E. 847 (1893) ; Cancemi v. People, 18 N. Y. 128 (1858); State v. Hudlins, 35 W. Va. 247,13 S. E. 367 (1S91); United States v. Perez, $\mathfrak{g}$ Theat. 579 (U. S. 1824); Keerl v. State, supra note 36; Anderzon v. State, 80 MId. 479, 38 Atl. 937 (1897).

See, generally, CooLey, Constirutional Lmimations (7th ed. 1903) 468 et seq; ClARK, op. cit. supra note 34, at 442 ct seq; 1 Bishop, op. cit. supra, at $\$ \S 998,1027,1028$; People v. Fochtman, supra note 29 (trial court on defendant's motion erroneously quashed the information after the jury had been impaneled and sworn).

3s Supra note 1, at 271, 30 Atl. at 1110. 
procedure; while such prosecution remains undetermined the one jeopardy has not been exhausted. . . . The same underlying principle of justice which demands a retrial because a juror is legally disqualified, calls for a retrial when illegal evidence has been admitted, or legal evidence excluded; in either case the trial is tainted and should not support a valid final judgment.

If such further proceedings are not authorized by law, the cause is ended, and the one jeopardy of the accused is exhausted; but this results not from any special sanctity attributable to a verdict tainted with illegality, but solely to the fact that the State, influenced by considerations of public policy, has decided to make such verdict, whether just or unjust, the end of that controversy. But when the State sees fit to provide that the cause shall not necessarily be so ended, but that further proceedings on motion of the accused may be had, an unjust verdict resumes its normal position of a legal nullity; and when the State provides for like proceedings on the motion of the prosecutor, a similar result must follow."

The reasoning of the court in the Lee case finds support in the dissenting opinion of Holmes, J., with whom concurred White and McKenna, J. J., in Kepner $v$. United States. ${ }^{39}$ The following excerpt will suffice:

"At the present time in this country there is more danger that criminals will escape justice than that they will be subjected to tyranny. But I do not stop to consider or to state the consequences in detail, as such considerations are not supposed to be entertained by judges, except as inclining them to one of two interpretations, or as a tacit last resort in case of doubt. It is more pertinent to observe that it seems to me that logically and rationally a man cannot be said to be more than once in jeopardy in the same cause, however often he may be tried. The jeopardy is one continuing jeopardy from its beginning to the end of the cause. [Our italics.] Everybody agrees that the principle in its origin was a rule forbidding a trial in a new and independent case where a man already had been tried once. But there is no rule that a man may not be tried twice in the same case. It has been decided by this court that he may be tried a second time, even for his life, if the jury disagree, United States v. Perez, 9 Wheat. 579 ; see Simmons v. United States, 142 U. S. 148; Logan $v$. United States, 144 U. S. 263; Thompson v. United States, 155 U. S. 271 , or notwithstanding their agreement and verdict, if the verdict is set aside on the prisoner's exceptions for error in the trial. Hopt v. People, 104 U.S. 631, 635; 110 U. S. $574 ; 114$ U. S. 488,$492 ; 120$ U. S. 430,442 ; United States v. Ball, 163 U. S. 662 , 672. He even may be tried on a new indictment if the judgment on the first is arrested upon motion. Ex parte Lange, 18 Wall. 163,$174 ; 1$ Bish. Crim. Law (5th ed.), § 998. I may refer fur. ther to the opinions of Kent and Curtis in People v. Olcott, 2 Johns. Cas. 301; S. C., 2 Day, 507, n.; United States v. Morris, 1 Curtis, 23, and to the well-reasoned decision in State v. Lee, 65 Connecticut, 265.

"If a statute should give the right to take exceptions to the

${ }^{39}$ Supra note 36 , at 134, 24 Sup. Ct. at 807. 
Government, I believe it would be impossible to maintain that the prisoner would be protected by the Constitution from being tried again. He no more would be put in jcopardy a second time when retried because of a mistake of law in his favor, than he would. be when retried for a mistake that did him harm. [Our italics.] It cannot matter that the prisoner procures the second trial. In a capital case, like Hopt $v$. People, a man cannot waive, and certainly will not be taken to waive without meaning it, fundamental constitutional rights. Thompson v. Utah, 170 U. S. 343, 353, 35.1. Usually no such waiver is expressed or thought of. MIoreover, it cannot be imagined that the law would deny to a prisoner the correction of a fatal error, unless he should waive other rights so important as to be saved by an express clause in the Constitution of the United States.

"It might be said that when the prisoner takes exceptions he only is trying to get rid of a jeopardy that already exists-that so far as the verdict is in his favor, as when he is found guilty of manslaughter upon an indictment for murder, according to some decisions he will keep it and can be retried only for the less offense, so that the jeopardy only is continued to the extent that it already has been determined against him, and is continued with a chance of escape. I believe the decisions referred to to be wrong, but, assuming them to be right, we must consider his position at the moment when his exceptions are sustained. The first verdict has been set aside. The jeopardy created by that is at an end, and the question is what shall be done with the prisoner. Since at that moment he no longer is in jeopardy from the first verdict, if a second trial in the same case is a second jeopardy even as to the less offense, he has a right to go free. In view of these difficulties it has been argued that on principle he has that right if a mistake of law is committed at the first trial. 1 Bish. Crim. Law (5th ed.), $\$ \$$ 999, 1017. But even MIr. Bishop admits that the decisions are otherwise, and the point is settled in this court by the cases cited above. That fetish happily being destroyed, the necessary alternative is that the Constitution germits a second trial in the same case. The reasor, hoverci, is not the fiction that $a$ man is not in jcopardy in case of a mislincetion, for it must be admitted that he is in jeopardy, evcn wien the error is patent on the face of the rccord, as whon he is tiricd on a defective indictment, [our italics] if judgment is not arrested. United States v. Ball, 163 U. S. 662. Moreover, if the fiction were true, it would be equally true when the misdirection was in favor of the prisoner. The icason, I suburit, is thent theire can be but one jeopardy in one casc. I have secin no other, encept the suggestion of waiver, and that I think cannot stand." [our italies].

The desirability of the Connecticut rule and the unfortunate effect of the majority rule are forcibly pointed out in the Pennsylvania case of Commonvealth v. Fitzpatrick, in applying the majority rule under protest, said:

"It [the plea of once in jeopardy] alleges only that ther'e might have been a conviction or an acquittal, if the judge trying the

40121 Pa. St. 109, 117, 15 Atl. 466, 468 (1S8S). 
cause had not made a mistake in law which prevented a verdict. It is of no consequence how many mistakes he makes, if the trial results in a conviction. The mistakes can be corrected on a writ of error and the defendant tried over again. But if the mistake results in closing the trial without a verdict, this is remediless. The court that made it cannot correct it. The proper court of review cannot correct it. The consequence is that a defendant charged with taking the life of his fellow man goes out of the court and out of the reach of justice because of a mistake in law made after an honest and painstaking effort to be right. Such was the case of Hilands v. Commonwealth. Such is this case. But the constitutional provision is plain and its enforcement by the courts has been uniform."

Reduced to its lowest terms, the use of the jeopardy doctrine in any degree to prevent appeal by the state results in an absurdity. What it amounts to is this: When the verdict of the jury favors the defendant, then the determination is and should be conclusive; when it favors the state, it is not and should not be conclusive. Stated thus baldly, the proposition is an amazing one. Calling it an application of the rule of former jeopardy is merely hiding behind convenient terminology. This fact has apparently been recognized in some jurisdictions, where it is expressly provided "that no person shall, after an acquittal, be tried for the same offence." [our italics]. ${ }^{41}$ Here we have a frank recognition of the proposition that the defendant is entitled to substantial advantages over the state in criminal prosecutions, which are not given to litigants in any other class of cases. This is an outgrowth of the same philosophy as that which permits the defendant to refuse to testify; which gives him the presumption of innocence; which gives the state the burden of proving guilt beyond a reasonable doubt; which permits the defendant to use the depositions of absent witnesses while denying that privilege to the state; which requires the state to set out a list of its witnesses in the indictment, but permits the defendant to conceal the names of his witnesses; which requires the state to set out its contentions in minute detail, but permits the defendant to raise such issues as insanity without notice during the trial; and which, in general, insists that it is better for nine guilty men to escape than that one innocent man should be punished. That philosophy applied to conditions of life and methods of crime as they exist in the United States seems to have produced a rather unhappy result. Our inquiry must be whether it is a philosophy which is still usable and workable to the same extent as in the days of its development; and particularly is it our duty to determine whether the methods of procedure originally devised for its application are still appropriate.

41 State v. Hart, supra note 20, at 269, 101 Atl. at 281; State v. Lee, 10 R. I. 494 (1873); State v. Wyse, 33 S. C. 582, 12 S. E. 556 (1890); State v. Kennedy, 96 Miss. 624, 50 So. 978 (1910) (acquittal or conviction). 
Considered as an original proposition in the light of present day conditions, it is hard to make out a case to support the contention that a man accused of crime would suffer any hardship as a result of an appeal, either in the appellate court or in a trial court to which his case would be returned for a new trial, which would be in any way disproportionate to the disadvantage which society now suffers from permitting an appeal by the accused. Let us consider, in order, further reasons which have been assigned for preserving in most jurisdictions this unequal condition.

First in importance, no doubt, is the idea that there is an almost sacred significance in the verdict of a "jury of his peers." Blackstone expresses the idea in terms which have been echoed and restated many times during the last one hundred and fifty years: 12

"Upon these accounts the trial by jury ever has been, and I trust ever will be, looked upon as the glory of the English law: And if it has so great an advantage over others in regulating civil property, how much must that advantage be heightened when it is applied to criminal cases! . . . it is the most transcendent privilege which any subject can enjoy, or wish for, that he cannot be affected either in his property, his liberty, or his person, but by the unanimous consent of twelve of his neighbors and equals. A constitution that I may venture to affirm has, under Providence, secured the just liberties of this nation for a long succession of ages. And therefore a celebrated French writer, who concludes that because Rome, Sparta, and Carthage have lost their liberties, therefore those of England in time must perish, should have recollected that Rome, Sparta, and Carthage, at the time when their liberties were lost, were strangers to the trial by jury. . . Here therefore a competent number of sensible and upright jurymen, chosen by lot from among those of the middle rank, will be found the best investigators of truth, and the surest guardians of public justice."

The argument continues that after a group of twelve men, representative of "this admirable constitution," have once declared an accused person to be innocent, no biased court should be permitted to declare otherwise "either by boldly asserting that to be proved which is not so, or by more artfully suppressing some circumstances, stretching and warping others, and distinguishing away the remainder." 43

As has been previously pointed out, Blackstone's eulogy vas spoken with reference to a time when the defendant in a criminal case was by no means so well protected as he is today, and at a time when the members of trial juries must needs be possessed of considerable courage themselves to withstand the coercion of

423 BL. Comm. $* 379$.

43 Ibid. 
judges. ${ }^{44}$ The changes which have taken place in criminal procedure since then have been described as "so great that a trial on a charge of crime now bears as little resemblance to one in the time of the Stuarts, as the service in a Christian church does to the heathen sacrifice to idols." 45 In the light of these changed conditions we are coming to regard the jury as a somewhat less hallowed institution. Roscoe Pound makes this temperate statement regarding its adoption in the United States: ${ }^{40}$

"The colonists had had experience of the close connection of criminal law with politics. The pioneers who had preserved the memory of this experience were not concerned solely to do away with the brutality of the old law as to felonies. Even more their constant fear of political oppression through the criminna law led them and the generation following, which had imbibed their ideas, to exaggerate the complicated, expensive and dilatory machinery of a common law prosecution, lest some safeguard of individual liberty be overlooked, to give excessive power to juries and to limit or even cut off the power of the trial judge to control the trial and hold the jury to its province . . . the community did not require the swift moving punitive justice, adjusted to the task of enforcing a voluminous criminal code against a multitude of offenders, which we demand today" [our italics].

On the other hand, much present day comment concerning the jury is by no means so temperate, and reputable legal periodicals are today giving space to articles carrying such titles as Abolish The Jury ${ }^{47}$ and Trial By Jury: An Ineffective Survival. ${ }^{48}$ There are few well-informed people today, who are sufficiently impressed with the caliber of trial juries or the quality of their verdicts, to suggest that a defendant should be concluded by an adverse verdict on all questions of law and fact. But when we concede so much in justifying the defendant's right of appeal, can we well avoid the conclusion that the state and the individual members of society which it represents are equally entitled to a further hearing?

There are some perhaps who would go even further in insisting that the jury's verdict of not guilty should be final, on the theory that, through the medium of such verdicts, jurys can and do exercise a necessary extra-legal control and restraint upon the enforcement of unwise or unpopular laws. That such control is now exercised, informed persons will not deny. Prosecuting attorneys do undoubtedly shape their policies upon the attitude of communities as expressed by juries. If juries consistently refuse to convict in particular types of cases, prosecutions of such

449 HoLdsworth, History OF ENGLish LAW (1926) 225.

451 BL. Comm. (Cooley's 2d ed. 1872) xxv.

46 The SPIRIT OF THE Common LAW (1921) 122.

47 McWhorter, 57 AM. L. REv. 42 (1923).

${ }^{48}$ Sebille, 10 AMr. B. A. J. 53 (1924). 
cases cease. Whether this is a desirable situation may not be so freely granted. The idea is clearly contrary to the legalistic conteption that general laws should not be varied in their administration according to local customs or prejudices. Conceding that the situation does exist and that some persons would defend it as proper, let us inquire what the effect of state appeals would be. A successful state appeal could be based only upon errors appearing in the record on appeal. If the record showed an errorless proceeding followed by a verdict of not guilty the appellate court could not reverse the judgment. It could not even reverse upon the ground that the evidence failed to sustain the verdict, as in civil cases; for the prosecution carries the burden of convincing the jury beyond a reasonable doubt, and if, in the particular case, the jury said that it was not convinced beyond a reasonable doubt, it would be indeed an omniscient court which could say that the jury was so convinced.

Assuming that error did appear and the case went back for a new trial another jury could if it wished again acquit in accordance with the will of the community. It may be contended that a reversal would have the effect of coercing the second jury into finding a verdict of guilty. It is doubtful if such a contention could be supported with any substantial evidence, but 'conceding its truth for the purpose of argument, then in a case so flagrant that an appellate court spoke so strongly as in fact to coerce a second jury and the jury was actually coerced; it is submitted that it were better for a community to be deprived of its prerogative of setting aside the law and compelled either to abide by the will of the majority as expressed in the law or to secure legislation changing it.

Let us consider next the argument that appeals by the state should not be permitted because we have already too many appeals. This contention, logically carried out, brings us to the conclusion that we should return to the old idea and permit no appeals at all in criminal cases. If there be any merit in the contention that a verdict of not guilty should be final and conclusive, there is no sound reason, under present day conditions, why a verdict of guilty should not be equally conclusive. We can safely assume, no doubt, that appeals by defendants will not be abolished, though there has been some tendency to limit them by prohibiting reversals upon technical errors which do not affect the substantial rights of accused persons. ${ }^{30}$ Conceding that appeals may have been too frequent or too freely allowed in the past, it must be remembered that those have been appeals by defendants and certainly the fact that appeals have been too

4 Calif. Const. art. VI, $\$ 4 y_{2}$; Calif. Penal Code (Deering, 1023) $\$ \S 960$, 1258, 1404; see (1925) 35 Yale Lat Jounnal, 105; State v. Anderson, 165 Minn. 150, 206 N. W. 51 (1925). 
freely allowed to defendants is no argument against allowing appeals to the state. It could equally well be said that there are too many appeals in civil cases, but surely no one would urge as a remedy for that situation that all appeals by plaintiffs should be prohibited.

If it be urged in this connection that over-zealous prosecutors would be apt to make many unwarranted appeals it can be safely answered that there is no danger of such a contingency. Probably the best demonstration of this point is to be found by an examination of the record of appealed cases in Connecticut since appeals by the state have been permitted. An examination of the appealed criminal cases which are reported in the Connecticut Reports, Volumes 82 to 98 , gives the following results:

Appealed by the state, 7: affirmed, 5 ; reversed, 2.

Appealed by defendants, 82 : affirmed, 56 ; reversed, 24 ; judgment for the defendant, 1; appeal dismissed, 1.

Reserved by the court, 2 : judgment for the state, 1 ; judgment for the defendant, 1 .

Both the cases appealed by the state and those reserved by the court involved questions of constitutionality of laws, of public policy or of the extent of jurisdiction of trial courts.

The experience of attorneys general, in states in which they are charged with representing the state on appeals taken by defendants, is that it is surprisingly difficult in most cases to maintain any interest in the case or to get substantial assistance from the attorney who prosecuted the case. The conventional picture of the blood-thirsty prosecutor is a far cry from that individual as he usually exists in real life. A moment's consideration of the tremendous "leakage" of cases in the course of prosecution, from arrest to verdict, ${ }^{50}$ will demonstrate clearly enough a fact well known to those about the criminal courts, that since the abandonment of the fee system, under which the prosecutor was paid according to the number of convictions which he obtained, the main object of that officer is to get rid of his cases as quickly, albeit as gracefully as possible.

The next argument advanced against state appeals is based upon the hardship which is involved for the defendant. It is urged that it would be eminently unfair to the individual defendant if the state, after dragging him through the weary procedure of the trial court, could keep its indictment hanging over him for an indefinite period, could require his appearance in the appellate court and then perhaps return him again to the trial court for a new trial. Considered in terms of an innocent, harrassed and indigent defendant, the argument is very persuasive. Considered in terms of a tricky crook or a depraved murderer

50 Pound, Criminal Justice in Cleverand (Chemical Foundation, 1922) 236-237. 
who has cheated justice by fraud and intimidation, it is not persuasive at all. As the issue to be determined in each case is guilt or innocence, we cannot assume innocence, but must consider the character of our procedure to determine whether it is adequate to protect both the individual defendant and society in emergencies. The defendant in a civil action may be equally unwilling and equally blameless, but we have no compunctions against permitting his adversary to exhaust him mentally and financially by resort to any court in which he can make a prima facie showing. There seems to be no clear reason why we should be so sort-hearted about permitting the state to take an appeal where the case is one of so much greater magnitude in its effect on society as to have been included within the scope of criminal law.

This argument is usually given point in terms of the hardships which would result from the great delay to which the accused would be subjected by being forced to await the result of an anpeal and perhaps a new trial. As a matter of fact, society has already much to apologize for on that score, and if the argument is conclusive, then we should abandon criminal prosecutions altogether. MTany a poor man has been financially ruined by long incarceration, awaiting the determination of the officers, whether prosecution should be commenced or not, awaiting the convening of a grand jury, or awaiting his turn on a crowded trial calendar. This objection presents no insurmountable obstacle so far as appeals are concerned. Criminal appeals could be given a preferred position on the calendar as is already done in some jurisdictions; ${ }^{51}$ special criminal divisions could be created as has been done in others; the time for perfecting appeals could be materially shortened; and, for that matter; the defendant could even be released on his own recognizance pending appeal. He would not be any freer then than he is now following absolute discharge. If the judgment were reversed he could be rearrested.

Some have suggested that the most important reason for preventing state appeals is that the defendant should not be required to stand the expense of an appeal. If this be regarded as a really great obstacle it can easily be taken care of by letting the state pay the costs, as is frequently done in the trial court, and as may be done in some jurisdictions when the defendant appeals.:2 This would place the defendant in a criminal case in an even

51 Morse v. United States, 168 Fed. 49 (1909); People v. Durrant, 119 Calif. 201, 51 Pac. 185 (1897); cf. State v. Peter, 13 La. Ann. 292 (135S); United States v. Norton, 91 U. S. 558 (1875); Stone v. State, 20 N. J. L. 404 (1845).

52 State v. Harris, 151 Iowa, 234, 130 N. T. 1082 (1911); People v. Willett, 1 How. Pr. (N. S.) 196 (N. Y. Sup. Ct. 18S5) ; Burden v. State, 70 Tex. Cr. App. 349, 156 S. W. 1196 (1913); State v. Fennimore, 2 Wash. 370, 26 Pac. 807 (1891). 
better position than a litigant in a civil case. It would perhaps also have a tendency to check unwarranted appeals. There would probably be little danger of that, however, for as has been previously pointed out, in most cases the prosecutor would be well content to abide by the verdict. The ultimate saving which would result from improved administration would far more than offset the cost which such a method would entail to the state. This will be spoken of at greater length.

The argument has been further supported on the theory that the reputation of the acquitted defendant would be materially

- injured by subjecting him to an appeal. If he be actually guilty, then the loss of reputation is a cost which society has adjudged to be a proper one. An appeal would do no more than has already been done in the trial court. If he be innocent, then his reputation would be in much better condition following a favorable decision by the appellate court than it was following a verdict in the trial court accompanied by whispers of jury bribery, intimidation of witnesses and corruption of judges. If the question involved be a vital one concerning matters of public policy, constitutional law or jurisdiction of courts, then, in the absence of a system which permits of declaratory judgments, the very continuance of the growth of the law requires that the individual litigant suffer the hardships incident to a proper final determination of the question by a competent court.

The foregoing are the arguments and reasons usually relied upon to support the rule prohibiting state appeals. Probably the real reason which has permitted a continuation of the discrimination is society's lack of interest in securing a better adjustment, coupled with a very active interest on the part of defense attorneys in preserving the advantages now enjoyed by them. A large percentage of our state legislators are lawyers. Generally these are men whose experience with criminal cases has been limited to the side of the defense. As a consequence they are alert to protect their own interests and the fate of any measure designed to put more teeth into criminal procedure is in their hands..$^{53}$ The other members of the legislature are usually willing to take the word of the lawyer members as to the desirability or undesirability of any proposed change in legal procedure, and there it ends. The experience of England in securing changes in her procedural law through the agency of a commission made up in large part of lay members is peculiarly suggestive. ${ }^{54}$

As has been already pointed out, the present-day prosecutor

53 Pound, Dedicatory Address (1925) 24 George Washington U. BulL. 15, at 19-21; Wigmore, Technicality in Indictments (1925) 16 Jour. OF Crim. Law and Crim. 166.

54 Sunderland, Handbook of Assochation of American Law Sohoots (1925) 74. 
is not usually inclined to urge any measure which means an increase in his labors. He has been made a victim of such a tremendous increase of duties resulting from the mass production of new legislation that he is rather inclined to become vocal in terms of protest. The courts are not anxious to increase their burdens and this may explain in part their opinions in the cases which have built up the present common law and Minnesota doctrine. The whole administration of criminal justice lacks motive power. ${ }^{55}$ The prosecuting witness has none of the personal interest of the litigant in a civil action. He soon wearies of the case, and is induced to quit, either by persuasion or intimidation. The average prosecutor will not even commence prosecution unless some person or agency is active in urging it. The result is that the business of defending criminals thrives and the survival of rules of procedure such as that prohibiting appeals by the state is made easy.

Now let us look at the other side of the question and examine some of the considerations favoring state appeals. While we cannot ruthlessly wipe out the advantages in procedure which have been built up for the accused over a long period of years we should honestly examine the matter from time to time to see whether the balance is relatively even. From the point of view of all the people who collectively make up the state, there can be no doubt that the success of the administration of criminal law as a protective agency is measured largely in terms of the apprehension and conviction of guilty persons. It is well lnown that many guilty persons are never apprehended, that many who are apprehended are never prosecuted and that many who are prosecuted are never convicted. ${ }^{56}$ The farther the process goes in each particular case, the greater the probability of guilt and the greater the capital outlay of investment which the state puts into making the process effective. Every conviction of a guilty man goes to make up the total of effective administration. Every guilty man who escapes conviction helps to break down effective administration and wastes the capital outlay which society has made for its protection. This may seem to be a cold-blooded method of appraisal, but the business of collecting taxes, building court houses, selecting officers, arresting and prosecuting criminals is itself a cold-blooded process. If the loss in suecessful prosecutions becomes proportionately great, the morale of the

${ }^{55}$ See Wigmore, op. cit. supra note 53; articles by the present writer in (1923) 46 ANNUAC REPORT AMI. BAR ASS'N 608, and Infomration or Indietments in Felony Cases (1924) 8 MINN. L. REv. 379, 384. A Kansas court held that the action of a Ku Klux Klan in sponsoring and aiding prosecution was laudable, apparently assuming that some such 2ssistance was necessary. State v. Stockton, 119 Kan. 868, 241 Pac. 688 (1025).

56 CRIMINAL Justice IN Cleveland, supra note 50, at 236, 237 et seq.; 8 MINN. L. REv. 379, 387, 403. 
whole administrative organization becomes low; criminals become bold, and the people, first scornful of the agencies which they have set up, are then in desperation apt to adopt extreme measures.

Does the fact that the state is not permitted to appeal contribute in any measure to the unfortunate situation suggested? Suppose that a prosecuting attorney deliberately misconducts himself in the prosecution of a case in order to induce an acquittal $;{ }^{57}$ suppose that a defense attorney so misconducts himself as to secure an acquittal and contemptuously disregards the rights of the state in presenting his client's case; ${ }^{\text {cs }}$ suppose that a trial judge, through ignorance, so incorrectly charges a jury that it acquits, or so deliberately evades the meaning and purpose of the law that he directs a dismissal or an acquittal.00 Can there be any question that the effect of a final conclusion of such a case by a jury's verdict must necessarily be an unfortunate one? Can there be any serious question that some way of avoiding such miscarriages of justice should be provided? Even permitting an appeal on questions of law, with the proviso that the acquitted defendant shall not be further concerned, as is done in some juris-

57 Shideler v. State, 129 Ind. 523,28 N. E. 537 (1891) ; petition for rehearing overruled, 129 Ind. 523, 29 N. E. 36 (1891); State v. Reed, 26 Conn. 201 (1857) ; State v. Moon, 41 Wis. 684 (1877); Attorney General v. Pelletier, 240 Mass. 264, 134 N. E. 407 (1922); Attorney General v. Tufts, 239 Mass. 458, 132 N. E. 322 (1921).

58 Luttrell v. State, 40 Tex. Cr. App. 651, 51 S. W. 930 (1899); see infra note 75 .

ธə 1 Bishop, op. cit. supra note 37, at $\S 1026$ (2); 2 WLLoughBY, op. cit. supra note 15, at 820; State v. Wong Hip Chung, 74 Mont. 523, 241 Pac. 620 (1925).

Brown, J., dissenting in Kepner v. United States, supra note 36 , at 137, 24 Sup. Ct. at 808:" "It seems to me impossible to suppose that Congress intended to place in the hands of a single judge the great and dangerous power of finally acquitting the most notorious criminals." But the majority of the court, stating the general rule prevailing in the United States held, at 133, 24 Sup. Ct. at 806: "The court of first instance, having jurisdiction to try the question of the guilt or innocence of the accused, found Kopner not guilty; to try him again upon the merits, even in an appellate court, is to put him a second time in jeopardy for the same offense, . . ."

United States v. Weissman, supra note 22, at 379, 45 Sup. Ct. at 136: "It is suggested that the course adopted in this case offers to the lower court a means of escaping the review allowed by the act; and there is an innuendo that there was a desire of that sort below. But such considerations do not affect the construction of the act, and it is fair to say that while the judge should not have directed a verdict when he did so, and if he thought the indictment bad should have quashed it before the jury came in, and left the question in form to be taken up, [our italics] still we see no sufficient reason for supposing that the direction was given with any notion of escaping the juxisdiction of this Court.

"Writ dismissed for want of jurisdiction."

State v. Gooch, 60 Ark. 218, 29 S. W. 640 (1895); Commonwealth v. Goulet, $140 \mathrm{Ky} .843,132$ S. W. 151 (1910). 
dictions, does not completely solve the problem; for if the prisoner be discharged following the verdict in the trial court and thereafter the appellate court determines that the verdict was reached as a result of error, the state finds itself in this anomalous position: that, on the one hand, it has consented to a discharge of the accused, free and clear of all punishment or blame; while, at the same time, its highest court has pronounced solemn judgment that he is or may be guilty of the crime charged against him.

In addition to our interest in securing a proper trial upon the merits in each case in order to prevent individual miscarriages of justice, there is further need of state appeals in order to secure a proper development of criminal law, both substantive and procedural. The unfortunate situation which now exists, in this respect, where the state is not permitted to appeal is illustrated by the following example: In a case prosecuted under a new statute, the defendant demurs to the indictment on the ground that it fails to state a public offense because the statute is unconstitutional. The court sustains the demurrer. In irinnesota that decision is final, at least for the county in which the prosecution takes place. ${ }^{\circ}$ An incidental result may be that in one county the law is operating one way and in another in an opposite way with no uniformity possible until a defendant chooses to raise the question on appeal. It seems rather remarkable, in a country which debates so violently, from time to time, the propriety of permitting the Supreme Court of the United States to pass on the constitutionality of legislative acts, that at the same time we tolerate a method which makes possible a final adjudication of unconstitutionality by a trial court.'01 This defect has been recognized even in some states which have persisted in prohibiting state appeals. $^{62}$ In others, as has been previously noted, ${ }^{c 3}$ re-

\footnotetext{
So State v. Johnson, 139 Minn. 500, 166 N. W. 123 (1918); Eee other Minnesota cases supra note 2.

¿1 See infra note 75; cf. Milton Dairy Co. v. G. N. Ry., 124 Minn. 290, 144 N. W. 764 (1914).

62 State v. Lee, supra note 41 , at 495: "The counsel contends that the jurisdiction is necessary to secure uniformity of decision. The want of such uniformity is doubtless an evil, but it is an evil which the people have chosen to run the hazard of, rather than expose a citizen who has once been fairly acquitted to the more perilous evil of repeated prosecution."

Commonwealth v. Cummings, st?pra note 6, at 213: "A worse uncertainty of the law can hardly be conceived, than that where the legislative acts of a government, by which all persons within its limits ought to be equally bound and protected, should receive a different final construction, in different judicial tribunals, and thus have a different operation upon those who are alike subject to them."

63 See supra note 12. State v. Dickerson, supra note 19, at 198, 76 N. E. at 864: "The right of appeal or to a review by proceedings in error is statutory (Wagner v. The State, 42 Ohio St., 537) and, when the right is given, it is a rule of interpretation that the right is given only to the
} 
views upon questions of law have been provided for the express purpose of settling questions of this character.

Another example is to be found in erroneous rulings of trial courts, adverse to the state, on points of law during the trial. The fact that such errors are committed is well known to practitioners and it is clearly revealed on appeal in jurisdictions which permit state appeals. ${ }^{64}$ Where no such appeals are allowed, of course in most cases no record is ever made in the appellate court upon such errors. Occasionally they appear in the defendant's record and the casual way in which the state's side of the case is then disposed of is well illustrated in a recent Missouri case: is

"The last point to be noticed is in reference to alleged improper conduct of counsel for the state in propounding certain questions and in argument of the case.

"In so far as the propounding of questions is concerned, the court sustained objections made to all of them to which counsel has called our attention, except one. No rebuke of counsel was asked. The propriety of sustaining all of such objections is not readily apparent to us. But, as the objections were sustained, they are out of the case" [our italics].

The same situation exists in connection with instructions given to the jury in the trial court. Here again the situation is occasionally revealed by comments of the appellate court. The following is a typical example from a recent federal case:

"The charge of the court certainly gave to the defendants and all of them all, if not more, than the law permitted, because the court apparently assumed that this was a borderline case and left the matter to the jury."

It is equally true that procedural law and the law of criminal evidence have suffered from a one-sided development, and it is probably true that the percentage of acquittals has been largely increased by the attitude of trial judges on these points. Cases proving this contention could be cited without number. An

defendant and not to the state, (State v. Simmons, 49 Ohio St., 305), consequently, if a trial court misconceived or misapplied the law, it might be impossible in that court to secure a conviction of a similar offense, [our italics] wherefore it is provided by section 7305, Revised Statutes, and the several sections following, that the prosecuting attorney may except to any decision of the court and apply to the supreme court for permission to file his bill of exceptions, for the decision of that court upon the points presented therein."

G See cases cited supra notes 8-14.

65 State v. Sloan, 309 Mo. 498, 517, 274 S. W. 734, 739 (1925).

${ }^{66}$ Sabbatino v. United States, 298 Fed. 409, 411 (C. C. A. 2d, 1924). Another example can be found in the case of Ford v. United States, 10 Fed. (2d) 339,349 (C. C. A. 9th, 1926) where the court said: "We think the charge was more favorable to these plaintiffs in error than they wero entitled to, ...." 
example which came within the writer's own experience and which will serve to illustrate it, is the case of Pcople v. Ah Leo decided by the District Court of Appeals of California, where the court in discussing the rulings of the trial court in the reception of evidence said:

"It is proper to add that the trial judge in this case vent even further than the law required him to go in restricting the purpose for which he allowed the evidence as to the acts committed by appellant on previous occasions with the complainant. Upon the objection being made to this testimony, the judge said: "Well, I will state to the jury that this evidence is not admitted for the purpose of the jury using any of the testimony to show that the defendant had committed those acts other than the one charged; it isn't admitted for the purpose of the jury using that testimony to establish the guilt of the defendant, but it is admitted for the jury to determine whether or not the defendant knew this boy at or prior to the time of the act charged; the jury will consider it only for that purpose; . . . The purpose for which such testimony in cases of this class is allowed is of a broader nature. The testimony is admitted as corroborative of the main charge and as tending to show the disposition of the aceused and his proneness to commit the crime of the particular nature involved. In this case the court considered the testimony only admissible for the purpose of strengthening the proof given by the complainant which went to the identity of the person who had indulged in the vicious relation with him."

It should be noted that in this case the evidence referred to by the appellate court was first ofiered by the prosecutor as corroborative of the main charge (a proper purpose) but was excluded by the trial judge. It was later offered again to rebut the appellant's testimony that he had never lnown the complainant and was received with the limitation stated. Had the appellant been acquitted the matter could never have been presented on appeal and a valuable decision on an important point would have been lost.

From the standpoint of the appellate court, too, it is desirable that the state should be permitted to raise points on appeal and that points so presented should not be mere moot questions. In some jurisdictions, as has been noted, appeals are permitted to review points of law. If the major purpose of such a review is to establish the law for the guidance of trial courts, then every facility should be provided to secure as full and adequate a presentation as possible. However, if the defendant be discharged upon a verdict of not guilty, or order's of the court, he steps out of the case and his side of it is not presented in the appellate court. Even when the case is contested, only too frequently the

67 28 Calif. App. 164, 166, 151 Pac. 748, 749 (1915). See also State v. Wakefield, 111 Or. 615, $22 S$ Pac. 115 (1924); Alt v. State, $85 \mathrm{Neb} .259$, 129 N. W. 432 (1911); State v. La Due, 164 Mlinn. 499, 205 N. W. 450 (1925) ; United States v. Weissman, supra note 22. 
court is not adequately assisted by counsel..$^{68}$ If the case were not contested, no matter how well presented it might be by the state, the court would have but one side of it. It was on exactly this ground that the United States Supreme Court held unconstitutional a provision in the statutes of the District of Columbia ${ }^{69}$ which attempted to give this limited right of appeal to the government in criminal cases. In the case of United States v. Evans, ${ }^{70}$ Fuller, C. J., speaking for the court, said:

"The appellee in such a case, having been freed from further prosecution by the verdict in his favor, has no interest in the question that may be determined in the proceedings on appeal, and may not even appear. Nor can his appearance be enforced. Without opposing argument, which is so important to the attainment of a correct conclusion, the court is called upon to lay down rules that may be of vital interest to persons who may hereafter be brought to trial. All such persons are entitled to be heard on all questions affecting their rights, and it is a harsh rule that would bind them by decisions made in what are practically "moot" cases, where opposing views have not been presented" [our italics].

The next consideration which makes important the granting to the state of a method of testing the trial court procedure is the demoralizing effect of the present method upon all parties concermed with the trial. Most reputable lawyers avoid criminal cases; most judges are anxious to get back to other phases of trial work. Why is this true? Because they realize that the emphasis of the present method is wrong and the scales of justice are off balance. Much of the delay in trial work and many of the obstructive tactics used are occasioned by this fact. A more orderly, balanced procedure would result in a tremendous saving in time and expense and in a more efficient administration of the law. The check and supervision which state appeals would give, would result in large measure in securing a more orderly, balanced procedure.

By way of illustration let us consider the effect of present methods on the various actors in a criminal prosecution. First of all, the lawyers. Consider the multitudinous grounds upon which appeals are taken by defendants. We grow righteously indignant, as we read the decisions, to learn of the errors committed against them, and of the indignities practiced upon them by the prosecuting attorney. Who does not know of inadmissible evidence "lugged in" to prejudice the jury, of improper arguments made by the prosecutor, of tricks and devices practiced by

68 People v. Niles, 300 Ill. 458, 133 N. E. 352 (1921).

${ }^{68}$ D. C. Ann. Code (1924) § 935, 31 Stat. 1341, c. 854, § 935, (1901)

U. S. Comp. Stat. (1916) § 1227.

${ }^{70} 213$ U. S. 297, 300, 29 Sup. Ct. 507, 508 (1908). 
him to gain the sympathy, or arouse the prejudice of the jury? As a matter of fact, conceding all of his well-known limitations, the one man in the court room who has best learned the danger of indiscretion in manner and speech is the prosecuting attorney. He is the one person whose actions are most frequently subject to recordation and inspection and who is most frequently informed by the supreme court as to just how he should behave.i2 But he knows that his only chance of successful prosecution is in the trial court. He knows that his sardonic opponent across the room, violating with impunity practically every rule of practice, and goading him deliberately into error, holds a whip hand against which it is almost impossible for him to compete. He knows that a record is being made of his words and actions upon which he may later be taken to task, but that he can make no record of the words or actions of the attorney for the defense which will serve any purpose.

Occasionally, even the trial judge, ${ }^{72}$ the jury and the other court officers, ${ }^{73}$ come in for advice and admonition. The one man who seems to be most privileged is the attorney for the defense. The recorded cases do not reveal his actions or speech except incidentally and by way of occasional justification or excuse for the prosecuting attorney. ${ }^{74}$ The reason is that the actions and speech of the attorney for the defense are not subject to review. ${ }^{75}$ If the state's attorney asks improper questions or

${ }^{71}$ See collections of cases in Am. Dig. Decennial, Crim. Lart, $\$ 699$ et scq.; 14 Cent. Dig., Crim. Law, § 1655 et scq.; (1925) 35 Yare Law Jounsar, 105.

72 Adler v. United States, 182 Fed. 464 (C. C. A. 5th, 1010); State v. Roby, 128 Minn. 187, 150 N. W. 793 (1915); People v. Becker, 210 N. Y. 274, 104 N. E. 396 (1914); Lewis v. State, 55 Fla. 54, 15 So. 998 (1908).

${ }^{73}$ Lavalley v. State, 188 Wis. 68, 205 N. W. 412 (1925).

7s State v. Giudice, 170 Iowa, 731, 153 N. W. 336 (1915); Irving V. People, 43 Colo. 260, 95 Pac. 940 (1908); People v. Kiely, 230 Mich. 403, 203 N. W. 112 (1925) ; State v. Burns, 119 Iowa, 663, 94 N. W. 238 (1903); Couch v. State, 6 Ala. App. 43, 60 So. 539 (1912); People v. Sliccovich, 193 Calif. 544, 226 Pac. 611 (1924); Roberts v. State, 60 Tex. Cr. App. 111, 131 S. W. 321 (1910).

In State v. Raymond, 88 Conn. 14s, 150, 89 Atl. 1118 (1914) appcars this comment: "In other respects mentioned, the attorney for the State was also guilty of gross impropriety. The record shows on his part, and on the part of the attorney opposed to him, a wilful disregard for the rulings and suggestions of the trial judge throughout the trial, and a similar disregard for the rules of court and the proprieties of the occasion. As coon as it appeared that this misconduct was wilful and not inadvertent, the trial judge should have admonished counsel that a repetition of it would be followed by their suspension or displacement as attorneys. If the admonition was unheeded, such displacement or suspension should hase been ordered."

75 The question presented is rather as to whether or not the defendant has been prejudiced by the retaliatory remarlss of the proseeuting attorney 
malres improper remarks, the defendant is prejudiced thereby and a hard-earned conviction is lost. If the same type of questions are asked or remarks made by the attorney for the defense, the state is not prejudiced and an acquittal so procured stands as a final determination. In civil cases it is quite common to find that misconduct of attorneys may constitute reversible error whether committed on behalf of either plaintiff or defendant. ${ }^{70}$ In criminal cases, strange to say, while the attorney for the defense may go so far as to put himself in contempt of court ${ }^{7 r}$ and subject himself to punishment, unless collusion on the part of defendant be shown, the acquittal stands.

In jurisdictions such as Minnesota there is no way, following , an acquittal, in which the conduct of the attorney for the defense can be brought to the attention of the appellate court. In fact, the more extreme his conduct or the more flagrant the court's error in ruling in the defendant's favor on matters of evidence or procedure, the more probable becomes an acquittal. The jury naturally gets the impression that the correct position is the one taken by the attorney for the defense and supported by the court. Sometimes the result is to distort the case out of all proportion and to make the prosecuting witness practically a defendant, harassed, browbeaten and unprotected, while the defendant sits smugly, not required to testify, and his silence not a proper subject of comment. Occasionally we find recognition of this warped situation in the opinions of appellate courts. ${ }^{78}$ However, if there be an acquittal, the state has no appeal and the appellate court never sees a record of the case. ${ }^{70}$ Those who are

or the disciplinary methods of the judge. See State v. Elder, 130 Wash. 612, 228 Pac. 1016 (1924) and see cases cited supra note 72.

${ }^{76}$ (1924) 8 MINN. L. Rev. 438; Illinois Power Co. v. Lyon, 311 Ill. '123, 142 N. E. 456 (1924); Wrabek v. Suchomel, 145 Minn. 468,177 N. W. 764 (1920).

${ }^{77}$ Goodhart v. State, 84 Conn. 60, 78 Atl. 853 (1911); In re Cary, 206 N. W. 402 (Minn. 1925).

78 State v. Sloan, supra note 65.

79 McCue v. State, 170 S. W. 280, 287 (Tex. Cr. App. 1914): "We always regret to see such exhibitions of temper, and strained technical criticisms of an opinion. - . . But it is sometimes insisted that we too often hold that, while some slight error has crept into the record against the defendant, yet it is not of that nature to necessitate a reversal of the case, and these technical matters are never held against the state. Counsel in their zeal forget that we never have an opportunity to so hold. The state has no right of appeal, and no matter how erroneous a ruling of the trial court may be against the state in regard to admitting or rojecting testimony, the state cannot bring those questions to us for review. On appeal all we pass on is: Was there error committed against the defendant on the trial of the case; and, if so, was it of the nature to harmfully affect him? . . . As hereinbefore stated, counsel in their zeal forget that only a defendant can appeal, and this court can and only does pass on whether or not there has been error committed against him-has he, 
familiar with criminal court practice know and take for granted the tremendous advantage which the defense has in this respect. To the uninitiated, who make only casual contact with the criminal courts, the chicanery and shysterism of the defense attorney is apt to be interpreted as evidence of great ability. The cautious prosecutor, with the latest warning of the appellate court still ringing in his ears, is apt to be regarded as a novice. ${ }^{30}$

As has been suggested before, the results of this situntion are far-reaching in their effect on the administration of the criminal law. The situation is demoralizing upon the trial judge. As a matter of practice and experience it can fairly be said that some trial judges do undoubtedly and deliberately weigh the scales in favor of the defendant. Such a judge lnows that if he rules for the defendant on all doubtful points and gives every instruction offered by him, he will be safe from reversal. If the instructions so given result in an acquittal, the state has no appeal and the matter ends there. If the jury convicts, then the record is clear. Some trial judges very franlily tell their prosecuting attorneys that they do not propose to take any chances of being reversed by giving instructions favoring the state on points disputed by counsel for the defendant. Some of them give every instruction requested by the defendant, even though the result be to state the same proposition of law and the same suggestion for acquittal over several times, and to give the jury an entirely false impression of the proper relative emphasis to be placed upon particular points.

The result is, further, that trial judges become more and more subject to local influence and local pressure in favor of the defendant. Few persons are interested in urging the trial judge to stand up squarely for law enforcement. Practically every defendant, on the other hand, has friends in the church, in the lodge, in the union, or in the social group who make it their business to whisper their suggestions and intimations in favor of leniency. The weak, spineless trial judge is able to hide his weakness in a record upon which the state has no appeal and thus to do the bidding of his friends. The strong, fearless judge acquires the reputation of being "hardboiled," of "railroading men to jail." If he rules on a disputed point in favor of the state and is reversed, he is punished from day to day by covert innuendoes and at election time by direct attack.

or not, had a fair and impartial trial? We have been led to malie these suggestions or remarks by the ill-timed expressions contained in the arguments on file, and we are satisfied that counsel, when they coolly reflect on the matter themselves, will admit that the use of the remarlis and expressions was wholly unwarranted and out of place" [our italics].

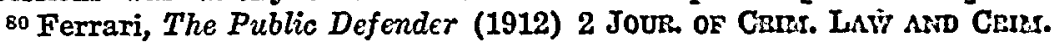
$704,707$. 
It is obvious that if the process were evened up by giving the state the privilege of taling appeals, these practices could not continue to thrive, so flourishingly at least. The spineless judge would act fairly or be soon exposed. It is not hard to predict that he would change his present methods. The strong judge would find some measure of support for his fearlessness, some protection from the politicians who seek to manipulate judicial processes and from the shyster lawyers who now harass him. ${ }^{81}$

The present situation is demoralizing, too, from the point of view of the police and other administrative officers. It is easy, for instance, to criticize the police and the prosecutor for allowing large numbers of cases to slip through their hands. They test their cases, however, according to standards which have been built up under the methods just described. If the police are satisfied that their best efforts cannot produce cases sufficient to satisfy the judges, why make arrests or why endeavor to develop evidence? ${ }^{82}$ If the prosecutor is convinced that he cannot prove a particular case "beyond a reasonable doubt" under the limitations which have been placed upon him, why should he go to trial with it? He is equally severely criticized for "persecuting" defendants in cases which do not merit prosecution.

The writer would not contend that all of the difficulties mentioned in this discussion could be avoided by providing for appeals by the state. However, it is submitted that very substantial improvement could be obtained. When we contemplate the reputed failure of our administration of criminal justice we cannot put our fingers on any one particular defect and say, here is the reason for our failure. We know, or think we know, that many guilty men are escaping: escaping detection, apprehension, conviction or punishment. It seems fair to assume that each one of many defects is contributing to that result, and that only by finding and remedying a number of them can we hope for sub. stantial improvement. Most members of the legal profession are willing to admit that the administration of criminal justice, as a whole, is in need of improvement. Our greatest difficulty lies in the unwillingness or inability of some of them to understand that only by making changes in particular rules and practices, each of which by itself may seem trifling or unnecessary, can we improve the administration of the whole.

81 Pound, Criminat JUSTice IN Cleveland, op. cit. supra not 50, at 603; State v. Elder, supra note 75. And see supra note 81 .

82 Waite, The Control of Crime (Feb. 1926) 137 ATLANTIC ManthuY, 214. 